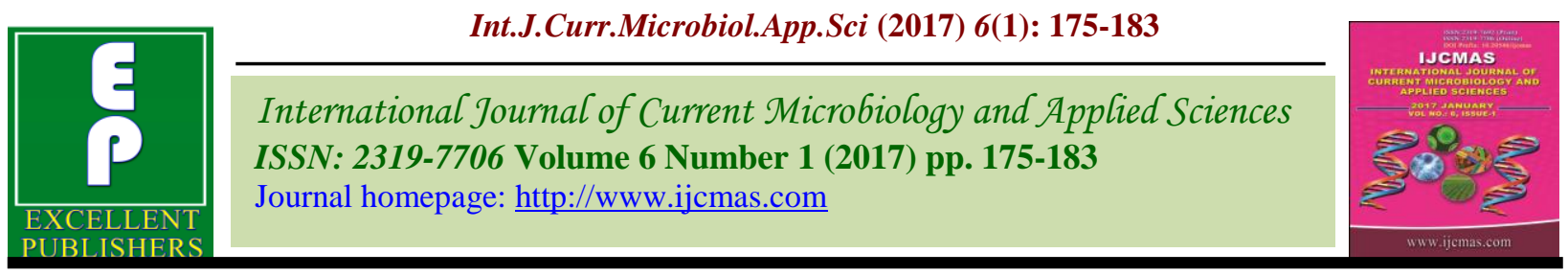

Original Research Article

http://dx.doi.org/10.20546/ijcmas.2017.601.022

\title{
Antimicrobial Resistance Pattern of Bacterial Isolates from Urinary Tract Infections at a Tertiary Care Centre
}

\author{
Puneet Bhatt*, Rajat Jagani, Praveer Ranjan, Mohd Ashraf Ali Namaji and \\ Khushi Ram Rathi
}

Graded Spl (Microbiology), Department of Pathology, Command Hospital, Pune-411040, India

*Corresponding author

\section{A B S T R A C T}

Urinary tract infections (UTIs) are the most common bacterial infections encountered in clinical practice, which cause morbidity in both hospitalized and out patients. Increasing antimicrobial resistance among bacterial uropathogens is a significant health concern. To

\section{Keywords}

Uropathogens ;

Nirofurantoin ; carbapenem ; colistin ; complicated UTIs.

Article Info

Accepted: 12 December 2016 Available Online: 10 January 2017 determine spectrum of microorganisms responsible for UTIs and their antimicrobial resistance pattern. Urine samples received in microbiology laboratory for culture from 17,135 patients clinically suspected of having urinary tract infection during the study period were processed according to standard protocol. Isolates were identified by conventional phenotypic methods and antibiotic resistance determined by Kirby Bauer disc diffusion method and Clinical and Laboratory Standards Institute (CLSI) guidelines. Out of 17,135 urine samples, $2731(15.9 \%)$ were considered as positive growth, which yielded 2760 isolates. The most common isolate was Escherichia coli (60.9\%) followed by Klebsiella pneumoniae (14.6\%), Pseudomonas aeruginosa (5.6\%), Enterococcus spp. (4.8\%), Staphylococcus aureus (4.2\%), Staphylococcus saprophyticus (3.0\%), Acinetobacter baumannii (2.9\%), Proteus spp. (2.6\%) and others (1.4\%). Most of the Gram-negative isolates showed resistance to fluoroquinolones, cephalosporins and aminoglycosides, whereas most Gram-positive isolates were found to be resistant to penicillins, co-trimoxazole and fluoroquinolones. Nitrofurantoin was the only drug which exhibited good sensitivity against both Gram-negative as well as Gram-positive isolates. E. coli and K. pneumoniae are the most common uropathogens. Nirofurantoin can be used for effective treatment as an emperical therapy for UTIs in OPD patients. Carbapenems and colistin should be reserved for complicated UTIs and prescribed only after sensitivity reports are available.

\section{Introduction}

Urinary tract infections (UTIs) are one of the most common bacterial infections, leading to increased morbidity in both hospitalized as well as outpatients (Tankhiwale et al., 2004; Mohajeri et al., 2014). Although, a variety of organisms are responsible for UTI, Escherichia coli and other members of the family Enterobacteriaceae account for a large majority of UTIs (Banerjee, 2009).
After Escherichia coli, the most common pathogens causing UTIs include Klebsiella pneumoniae, Enterococcus spp., $S$. saprophyticus, Pseudomonas aeruginosa, Candida spp., Proteus spp. and Enterobacter spp (Noor et al., 2013).

Increasing prevalence, relapse and ramifications in eradication of UTI make it a 
cause for concern and present a real challenge to healthcare professionals. It is also a known fact that women are more vulnerable to UTI due to anatomical and physiological factors. Owing to its position, urogenital tract of women is more susceptible to bacterial infections caused by both internal and external flora.

Increasing drug resistance in bacterial uropathogens is an important and emerging public health problem. The distribution of antimicrobial susceptibility data of UTIcausing microorganisms changes from place to place. Generally, the antimicrobial treatment is initiated before the culture sensitivity results are available which may lead to the frequent misuse of antibiotics (Prakash et al., 2013). The current knowledge of the organisms causing UTI and their antimicrobial susceptibility pattern is a necessity, in order to ensure appropriate empirical therapy. In view of the increasing antimicrobial resistance among bacterial isolates causing UTI, this study was undertaken at a tertiary care centre to determine the spectrum of microorganisms responsible for UTI and their antimicrobial resistance pattern.

\section{Materials and methods}

\section{Study population}

This cross sectional study was carried out from June 2014 to May 2016 in Microbiology laboratory of a tertiary care centre. A total of 17,135 patients clinically suspected of having urinary tract infections with complaints of fever, frequency or urgency of micturition were involved which included both inpatients and out-patients.

\section{Collection of Sample}

The patients were thoroughly instructed on how to collect the urine samples with strict asepsis. Clean-catch mid-stream samples were collected from each patient. In case of children, the urine sample was collected by suprapubic aspiration. In catheterized patients, the catheter was clamped and the area proximal to the clamp was disinfected. Then, using a 28 gauge needle and syringe, urine was withdrawn. The samples were immediately transported to microbiology laboratory for further processing.

\section{Processing of Sample}

A standard calibrated bacteriological loop was used to inoculate $0.01 \mathrm{ml}$ of urine sample on Cysteine Lactose Electrolyte Deficient (CLED) medium. The plates were then incubated at $37^{\circ} \mathrm{C}$ for 24 hours.

\section{Interpretation of Growth and Identification of Isolates}

A sample was considered positive for UTI if the colony count was more than $10^{5}$ $\mathrm{CFU} / \mathrm{ml}$ by semi-quantitative technique and the direct microscopy revealed pus cells $\geq 8 / \mathrm{cu} \mathrm{mm}^{5}$. All the isolates were identified at the species level by standard biochemical tests. Samples growing more than two (02) organisms were not included in the study and were discarded as mixed growth. Urine samples with no growth after 48 hours of incubation were considered as negative.

\section{Antimicrobial susceptibility testing}

Antimicrobial sensitivity testing of all Gramnegative and Gram-positive isolates was carried out by Kirby-Bauer disc diffusion method and the results were interpreted according to Clinical and Laboratory Standards Institute (CLSI) guidelines. Gram-negative isolates which were found to be resistant to all tested antibiotics by disc diffusion method, were tested for Colistin susceptibility by determination of minimum inhibitory concentration (MIC) using E-test 
method. Vancomycin susceptibility for Gram-positive isolates was also tested by Etest method using vancomycin E-strips, as there are no disc diffusion guidelines for interpretation.

\section{Results and Discussion}

During the two year period of study, a total of 17,135 urine samples were received in microbiology laboratory. Out of these urine samples, only 2731 samples (15.9\%) were considered as positive growth which yielded 2760 isolates. This was because 29 samples showed growth of two pathogens.

Out of 2731 samples which yielded bacterial growth and were considered positive for UTI, 1721 samples (63\%) were from female patients and 1010 samples $(37 \%)$ were from male patients. The age of the patients ranged from 3 months to 86 years with a mean of 33 years. The mean ages of male and female patients were 38.3 and 31.1 years respectively. The age and sex-wise distribution of positive urine cultures is shown in Table 1.

Out of 17,135 samples, 1156 were from patients admitted in ICU, 7053 from patients admitted in different wards of the hospital and 8926 were from OPD patients. A total of 199 samples from ICU (17.2\%), 1136 from wards (16.1\%) and 1396 from OPD (15.6\%) yielded positive growth.

Out of 2760 isolated organisms, 1681 (60.9\%) were E. coli, 403 (14.6\%) were Klebsiella pneumoniae, 159 (5.6\%) were Pseudomonas aeruginosa, 132 (4.8\%) were Enterococcus spp., 115 (4.2\%) were Staphylococcus aureus, 81 (3.0\%) were Staphylococcus saprophyticus, 79 (2.9\%) were Acinetobacter baumannii, 73 (2.6\%) were Proteus spp. and 37 (1.4\%) were other species. A total of 2420 Gramnegative isolates and 340 Gram-positive isolates were obtained from these urine samples of 2409 and 322 patients respectively.

The antimicrobial resistance profile of 2420 Gram-negative and 340 Grampositive isolates is shown in Table 2 and Table 3 respectively.

Urinary tract infections (UTIs) are one of the most common infections affecting all age groups and both sexes. They are the most frequent cause of morbidity in patients attending OPD and are also the most common healthcare-associated infection (Sussman, 1998). The most common uropathogens belong to the family Enterobacteriaceae such as Escherichia coli and Klebsiella pneumoniae followed by Pseudomonas aeruginosa, Staphylococcus spp., and Acinetobacter baumannii.

UTI is a common, yet serious ailment in humans due to its recurrence and complexity in eradication. This problem is compounded by the declining number of newer antimicrobial agents entering the clinical practice and increasing antimicrobial resistance.

This study comprised of a total of 17,135 non-repetitive urine samples received in microbiology laboratory, out of which only 2731 samples were considered as positive growth which yielded 2760 isolates. After detailed review of the literature, it has been found that this study is one of the largest studies on antimicrobial resistance pattern of uropathogens, as far as sample size and number of isolates is concerned (Kibret et al., 2014; Momoh et al., 2011). Our study revealed a positivity rate of $15.9 \%$ (2731/17135) which is much lower as compared to other studies of Banerjee (24.5\%), Prakash et al., (53.8\%), Kibret et al., (22.7\%) and Momoh et al., (49\%). 
In the present study, out of 2731 samples which yielded bacterial growth and were considered positive for UTI, 1721 samples $(63 \%)$ were from female patients and 1010 samples $(37 \%)$ were from male patients. Similar findings regarding the sex distribution of positive urine samples have been reported in a study by Banerjee. However, Kibret et al., showed a higher number of female patients being affected by urinary tract infections (Kibret et al., 2014). Although, urinary tract infections affect both sexes, it is a well known fact that it is more common in females as compared to males because of shorter urethra in females which is less effective for preventing bacterial entry and closer proximity of urethral meatus and anal opening (Warren et al., 1999).

In the present study, the age of the patients observed varied from 3 months to 86 years. The mean age of all patients was 33 years and that of male and female patients being 38.3 and 31.1 years respectively. It was observed that in both sexes, the maximum number of uropathogens were isolated from the patients in the age group 31-40 years. Similar findings were seen in a study by Kibret et al., in which the mean age was found to be 32.26 years and that of male and females patients was 35.1 and 30.78 years respectively.

The present study shows that the OPD patients formed the highest sample size followed by samples from wards and ICU. However, the positivity rate was highest from ICU samples followed by wards and OPD samples. This might be attributed to the fact that many of the OPD samples yielded growth of more than two organisms which signifies improper specimen collection techniques. Moreover, it also shows the unwarranted ordering of urine cultures from OPD patients, which are often not required. The causative organisms responsible for UTI are fairly well known and various studies have not offered significant differences. In our study, Escherichia coli $(60.9 \%)$ was the found to be the predominant isolate followed by Klebsiella pneumoniae (14.6\%), Pseudomonas aeruginosa (5.6\%), Enterococcus spp. (4.8\%), Staphylococcus aureus (4.2\%), Staphylococcus saprophyticus (3.0\%), Acinetobacter baumannii (2.9\%), Proteus spp. (2.6\%)and other species (1.4\%). These findings are consistent with other studies which also reveal that $E$. coli and $K$. pneumoniae are the commonest pathogens responsible for urinary tract infections (Barnett et al., 1997; Moges et al., 2002; Wagenlehner et al., 2004). It was clear from our study that Gram-negative bacteria were more responsible for UTI than Gram-positive bacteria, which is in concordance with the findings of previous studies (Ojumba, 2005).

Empiric antibiotic therapy is the mainstay of treatment for UTIs. However, many previous studies indicate increasing trend of drug resistance among UTI pathogens. As it is clear from Table 2, in our study, 68-82\% of the E.coli isolates were found to be resistant to ceftazidime, cefepime, ampicillin and gentamicin, 55-60\% isolates were resistant to piperacillin + tazobactum, ampicillin+ sulbactum and amoxicillin+clavulanate. The antibiotics with least resistance was found to be imipenem (12\%) followed by nitrofurantoin (15\%).

Isolates of $K$. pneumoniae were found to be more resistant. In our study, $61-90 \%$ of isolates were resistant to amoxicillin + clavulanic acid, ampicillin+ sulbactum, piperacillin + tazobactum, cefepime, ceftazidime and gentamicin. Ninety nine percent $(99 \%)$ of isolates were sensitive to colistin and $67 \%$ were sensitive to nitrofurantoin. The resistance levels are too high when compared to studies done by Kibret et al., (2004). 
Table.1 Age and sex-wise distribution of positive urine cultures

\begin{tabular}{ccccc}
\hline $\begin{array}{c}\text { Age group } \\
\text { (years) }\end{array}$ & Number & \%age & Number & \%age \\
\hline $\mathbf{0 - 1 0}$ & 129 & $7.5 \%$ & 88 & $8.7 \%$ \\
$\mathbf{1 1 - 2 0}$ & 289 & $16.8 \%$ & 146 & $14.5 \%$ \\
$\mathbf{2 1 - 3 0}$ & 273 & $15.9 \%$ & 133 & $13.2 \%$ \\
$\mathbf{3 1 - 4 0}$ & 478 & $27.8 \%$ & 266 & $26.3 \%$ \\
$\mathbf{4 1 - 5 0}$ & 245 & $14.2 \%$ & 198 & $19.6 \%$ \\
$\mathbf{5 1 - 6 0}$ & 190 & $11.0 \%$ & 122 & $12.1 \%$ \\
$>\mathbf{6 0}$ & 117 & $6.8 \%$ & 57 & $5.6 \%$ \\
\hline Total & 1721 & - & 1010 & - \\
\hline
\end{tabular}

Table.2 Antimicrobial resistance profile of Gram-negative urinary isolates

\begin{tabular}{|c|c|c|c|c|c|c|}
\hline $\begin{array}{l}\text { S. } \\
\text { No. }\end{array}$ & Antimicrobial & $\begin{array}{l}\text { E. coli } \\
\text { (1681) }\end{array}$ & $\begin{array}{c}\text { K. pneumoniae } \\
(403)\end{array}$ & $\begin{array}{c}\text { P. aeruginosa } \\
(159)\end{array}$ & $\begin{array}{c}\text { A.baumannii } \\
\text { (79) }\end{array}$ & $\begin{array}{l}\text { Proteus spp. } \\
\text { (73) }\end{array}$ \\
\hline 1. & $\begin{array}{c}\text { Ampicillin } \\
(10 \mu \mathrm{g})\end{array}$ & $\begin{array}{c}1378 \\
(82 \%)\end{array}$ & Not tested & Not tested & Not tested & $\begin{array}{c}62 \\
(85 \%)\end{array}$ \\
\hline 2. & $\begin{array}{c}\text { Amoxycillin }+ \\
\text { Clavulanic acid } \\
(20 \mu \mathrm{g}+10 \mu \mathrm{g})\end{array}$ & $\begin{array}{c}1009 \\
(60 \%)\end{array}$ & $\begin{array}{c}322 \\
(80 \%)\end{array}$ & Not tested & Not tested & $\begin{array}{c}57 \\
(78 \%)\end{array}$ \\
\hline 3. & $\begin{array}{c}\text { Ampicillin }+ \\
\text { Sulbactum } \\
(10 \mu \mathrm{g}+10 \mu \mathrm{g})\end{array}$ & $\begin{array}{c}992 \\
(59 \%)\end{array}$ & $\begin{array}{c}314 \\
(78 \%)\end{array}$ & Not tested & $\begin{array}{c}26 \\
(33 \%)\end{array}$ & $\begin{array}{c}48 \\
(66 \%)\end{array}$ \\
\hline 4. & $\begin{array}{c}\text { Piperacillin }+ \\
\text { Tazobactum } \\
(100 \mu \mathrm{g}+10 \mu \mathrm{g})\end{array}$ & $\begin{array}{c}924 \\
(55 \%)\end{array}$ & $\begin{array}{c}314 \\
(78 \%)\end{array}$ & $\begin{array}{c}125 \\
(79 \%)\end{array}$ & $\begin{array}{c}71 \\
(90 \%)\end{array}$ & $\begin{array}{c}44 \\
(60 \%)\end{array}$ \\
\hline 5. & $\begin{array}{l}\text { Cefepime } \\
(30 \mu \mathrm{g})\end{array}$ & $\begin{array}{c}1294 \\
(77 \%)\end{array}$ & $\begin{array}{c}363 \\
(90 \%)\end{array}$ & $\begin{array}{c}146 \\
(92 \%)\end{array}$ & $\begin{array}{c}71 \\
(90 \%)\end{array}$ & $\begin{array}{c}62 \\
(85 \%)\end{array}$ \\
\hline 6. & $\begin{array}{l}\text { Ceftazidime } \\
(30 \mu \mathrm{g})\end{array}$ & $\begin{array}{l}1176 \\
(70 \%)\end{array}$ & $\begin{array}{c}342 \\
(85 \%)\end{array}$ & $\begin{array}{c}137 \\
(86 \%)\end{array}$ & $\begin{array}{c}64 \\
(81 \%)\end{array}$ & $\begin{array}{c}61 \\
(84 \%)\end{array}$ \\
\hline 7. & $\begin{array}{c}\text { Imipenem } \\
(10 \mu \mathrm{g})\end{array}$ & $\begin{array}{c}201 \\
(12 \%)\end{array}$ & $\begin{array}{c}197 \\
(49 \%)\end{array}$ & $\begin{array}{c}73 \\
(46 \%)\end{array}$ & $\begin{array}{c}53 \\
(67 \%)\end{array}$ & $\begin{array}{c}16 \\
(22 \%)\end{array}$ \\
\hline 8. & $\begin{array}{c}\text { Gentamicin } \\
(10 \mu \mathrm{g})\end{array}$ & $\begin{array}{c}571 \\
(34 \%)\end{array}$ & $\begin{array}{c}246 \\
(61 \%)\end{array}$ & $\begin{array}{c}86 \\
(54 \%)\end{array}$ & $\begin{array}{c}60 \\
(76 \%)\end{array}$ & $\begin{array}{c}39 \\
(53 \%)\end{array}$ \\
\hline 9. & $\begin{array}{l}\text { Ciprofloxacin } \\
(5 \mu \mathrm{g})\end{array}$ & $\begin{array}{c}1143 \\
(68 \%)\end{array}$ & $\begin{array}{c}314 \\
(78 \%)\end{array}$ & $\begin{array}{c}87 \\
(55 \%)\end{array}$ & $\begin{array}{c}64 \\
(81 \%)\end{array}$ & $\begin{array}{c}51 \\
(70 \%)\end{array}$ \\
\hline 10. & $\begin{array}{c}\text { Co-trimoxazole } \\
(1.25 \mu \mathrm{g}+23.75 \\
\mu \mathrm{g})\end{array}$ & $\begin{array}{c}689 \\
(41 \%)\end{array}$ & $\begin{array}{c}173 \\
(43 \%)\end{array}$ & Not tested & $\begin{array}{c}42 \\
(53 \%)\end{array}$ & $\begin{array}{c}32 \\
(44 \%)\end{array}$ \\
\hline 11. & $\begin{array}{c}\text { Nitrofurantoin } \\
(300 \mu \mathrm{g})\end{array}$ & $\begin{array}{c}252 \\
(15 \%)\end{array}$ & $\begin{array}{c}133 \\
(33 \%)\end{array}$ & Not tested & Not tested & $\begin{array}{c}13 \\
(18 \%)\end{array}$ \\
\hline 12. & Colistin (MIC) & Nil & $\begin{array}{c}4 \\
(1 \%)\end{array}$ & $\begin{array}{c}3 \\
(2 \%)\end{array}$ & Nil & Not tested \\
\hline
\end{tabular}


Table.3 Antimicrobial resistance profile of Gram-positive urinary isolates

\begin{tabular}{|c|c|c|c|c|}
\hline $\begin{array}{c}\text { S. } \\
\text { No. }\end{array}$ & Antimicrobial & $\begin{array}{c}\text { Enterococcus spp. } \\
\text { (115) }\end{array}$ & $\begin{array}{l}\text { S. aureus } \\
(\mathrm{81})\end{array}$ & $\begin{array}{c}\text { S. saprophyticus } \\
\text { (79) }\end{array}$ \\
\hline 1. & $\begin{array}{l}\text { Penicillin } \\
\text { (10 units) }\end{array}$ & $\begin{array}{c}61 \\
(53 \%)\end{array}$ & $\begin{array}{c}77 \\
(95 \%)\end{array}$ & $\begin{array}{c}75 \\
(95 \%)\end{array}$ \\
\hline 2. & $\begin{array}{l}\text { Cefoxitin } \\
(30 \mu \mathrm{g})\end{array}$ & Not tested & $\begin{array}{c}42 \\
(52 \%)\end{array}$ & $\begin{array}{c}26 \\
(33 \%)\end{array}$ \\
\hline 3. & $\begin{array}{l}\text { Co-trimoxazole } \\
(1.25 \mu \mathrm{g}+23.75 \mu \mathrm{g})\end{array}$ & Not tested & $\begin{array}{c}38 \\
(47 \%)\end{array}$ & $\begin{array}{c}34 \\
(43 \%)\end{array}$ \\
\hline 4. & $\begin{array}{l}\text { Tetracycline } \\
\quad(10 \mu \mathrm{g})\end{array}$ & $\begin{array}{c}70 \\
(61 \%)\end{array}$ & $\begin{array}{c}13 \\
(16 \%)\end{array}$ & $\begin{array}{c}15 \\
(19 \%)\end{array}$ \\
\hline 5. & $\begin{array}{l}\text { Ciprofloxacin } \\
\qquad(5 \mu \mathrm{g})\end{array}$ & $\begin{array}{c}85 \\
(74 \%)\end{array}$ & $\begin{array}{c}43 \\
(53 \%)\end{array}$ & $\begin{array}{c}38 \\
(48 \%)\end{array}$ \\
\hline 6. & $\begin{array}{l}\text { Amikacin } \\
(30 \mu \mathrm{g})\end{array}$ & Not tested & $\begin{array}{c}17 \\
(21 \%)\end{array}$ & $\begin{array}{c}15 \\
(19 \%)\end{array}$ \\
\hline 7. & $\begin{array}{c}\text { High-level Gentamicin } \\
\qquad(120 \mu \mathrm{g})\end{array}$ & $\begin{array}{c}77 \\
(67 \%)\end{array}$ & Not tested & Not tested \\
\hline 8. & $\begin{array}{l}\text { Vancomycin } \\
\text { (MIC) }\end{array}$ & $\begin{array}{c}22 \\
(19 \%)\end{array}$ & Nil & Nil \\
\hline 9. & $\begin{array}{l}\text { Linezolid } \\
(30 \mu \mathrm{g})\end{array}$ & $\begin{array}{c}8 \\
(7 \%)\end{array}$ & Nil & Nil \\
\hline 10. & $\begin{array}{l}\text { Nitrofurantoin } \\
(300 \mu \mathrm{g})\end{array}$ & $\begin{array}{c}30 \\
(26 \%)\end{array}$ & $\begin{array}{c}13 \\
(16 \%)\end{array}$ & $\begin{array}{c}11 \\
(14 \%)\end{array}$ \\
\hline
\end{tabular}

Seventy three (73) $-92 \%$ of isolates of $P$. aeruginosa were resistant to most commonly used antibiotics with antipseudomonal activity like piperacillin+tazobactum, cefepime and ceftazidime. The reserve drug Colistin being the only drug which is sensitive against $P$. aeruginosa isolates, which is in agreement with the studies done by Shanti et al., Shah et al., and Somashekara et al., (2014).

Considering the fact that, E.coli and $K$. pneumoniae constitute around $75 \%$ of the etiological agents, nitrofurantoin can be judiciously used as a first line antibiotic in treating community acquired UTIs. Strikingly, most of the gram negative isolates were resistant to third and fourth generation cephalosporins and the commonly used antibiotic $\beta$-lactam and $\beta$ lactamase inhibitor combinations, which portrays the inappropriate and injudicious use of these antibiotics as empirical therapy. Hence necessitates the need for an antibiotic policy in every hospital as per Chennai Declaration.

Among the gram positive isolates, $61-85 \%$ isolates of Enterococcus spp., which are the most common Gram-positive uropathogens, were resistant to most of antibiotics including penicillin, tetracycline, high-level gentamicin and ciprofloxacin. It was also seen that $22 \%$ of the isolates were resistant to vancomycin, $30 \%$ to nitrofurantoin. Fortunately, only $8 \%$ isolates were resistant to linezolid, which is the last line of defense against Enterococcus spp. Among $S$. aureus, $52 \%$ isolates were methicillin resistant, which signifies resistance to all $\beta$ lactam antibiotics except the $5^{\text {th }}$ generation cephalosporins with anti-MRSA activity. 
Around $43 \%$ isolates were also resistant ciprofloxacin which is higher as compared to study by Onanuga et al. Nitrofurantoin was the only antibiotic which showed acceptable sensitivity and only $13 \%$ isolates were resistant to it which is much

lesser as compared to study by Onanuga A et al., (2012).

Staphylococcus saprophyticus was the $3^{\text {rd }}$ most common Gram-positive uropathogen. Around $95 \%$ of these isolates were found to be resistant to penicillin, $38 \%$ to ciprofloxacin, $34 \%$ to co-trimoxazole and $26 \%$ of isolates were resistant to cefoxitin, which signifies methicillin-resistance. This resistance pattern is much higher as compared to the study of Jhora et al., who reported only $9 \%$ resistance to ciprofloxacin and $17 \%$ to co-trimoxazole ${ }^{28}$. In our study, only $14 \%$ isolates were found to be resistant to nitrofurantoin, which was comparable to study of Jhora et al., who reported $15 \%$ resistance. The major limitation of the study is that it did not distinguish the distribution of organisms in the community acquired UTI and nosocomial UTI. As a consequence, the prevalence of microorganisms and their resistance pattern in both types of UTI could not be ascertained.

In conclusion, this study provides the details about common uropathogens and their antimicrobial resistance pattern. It is clear that, E. coli and $K$. pneumoniae are still the most common uropathogens. Antibiotics such as $\beta$-lactams, co-trimoxazole, and fluoroquinolones have limited value for the treatment of UTI. Sensitivity to imipenem and colistin are still retained and may be prescribed for complicated UTI. Nitrofurantoin has good sensitivity against Gram-negative as well as Gram-positive bacteria and can be used as an effective treatment especially for OPD patients. Routine monitoring of resistance patterns is necessary, which will help the clinicians in the empirical treatment of UTI and also for preparation of an antibiotic policy.

\section{References}

Banerjee, S. 2009. The Study of Urinary Tract Infections and Antibiogram of Uropathogens in and around Ahmednagar, Maharashtra. The Internet J. Infect. Dis., 9(1): http://ispub.com/IJID/9/1/10376.

Barnett, B.J., Stephens, D.S. 1997. Urinary tract infections: an over view. Am. J. Med. Sci., 314: 245-9.

Beyene, G., Tsegaye, W. 2011. Bacterial uropathogens in urinary tract infection and antibiotic susceptibility pattern in Jimma University Hospital, Ethiopia. Ethiop. J. Health Sci., 21: 141-6.

Clinical and Laboratory Standards Institute. 2014. Performance Standards for Antimicrobial Susceptibility. TwentyFourth Information supplement. CLSI document M100-S24. CLSI, Wayne, PA.

Clinical and Laboratory Standards Institute. 2015. Performance Standards for Antimicrobial Susceptibility. TwentyFourth Information supplement. CLSI document M100-S25. CLSI, Wayne, PA.

Clinical and Laboratory Standards Institute. 2016. Performance Standards for Antimicrobial Susceptibility. TwentyFourth Information supplement. CLSI document M100-S26. CLSI, Wayne, PA.

Jhora, S.T., Paul, S. 2011. Urinary Tract Infections caused by Staphylococcus saprophyticus and their antimicrobial sensitivity pattern in Young adult Women. Bangladesh J. Med. Microbiol., 5(1): 21-5. 
Kibret, M., Abera, B. 2014. Prevalence and antibiogram of bacterial isolates from urinary tract infections at Dessie Health Research Laboratory, Ethiopia. Asian Pac. J. Trop. Biomed., 4(2): 164-8.

Kumar, Y., Sood, S., Sharma, A., Mani, K.R. 2013. Antibiogram and characterization of resistance markers among Escherichia coli isolates from urinary tract infections. J. Infect. Dev. Ctries, 7 (7): 513-9.

Maripandi, A., Al-Salamah, A.A., Amuthan, M. 2010. Prevalence and Antibiotic Susceptibility of Uropathogens in Patients from a Rural Environment, Tamil Nadu. American J. Infect. Dis., 6 (2): 29-33.

Moges, A.F., Genetu, A, and Mengistu, G. 2002. Antibiotic sensitivities of common bacterial pathogens in urinary tract infection at Gondar Hospital, Ethiopia, East Afr. Med. J., 79: 140-2.

Mohajeri, P., Darfarin, G., Farahani, A. 2014. Genotyping of ESBL Producing UropathogenicEscherichia coli in West of Iran. Int. J. Microbiol., http://dx.doi.org/10.1155/2014/276941

Momoh, A.R.M., Orhue, P., Idonije, O.B., Oaikhena, A.G., Nwoke, E.O., Momoh, A.A. 2011. The antibiogram types of Escherichia coli isolated from suspected urinary tract infection samples. J. Microbiol. Biotech. Res., 1(3): 57-65.

Nassar NT. Management of urinary tract infections. J Med Liban 2000; 79: 1402.

Noor, A.F., Shams, F., Munshi, S.K., Hassan, M., Noor, R. 2013. Prevalence and Antibiogram Profile of Uropathogens isolated from Hospital and Community Patients with Urinary Tract Infections in Dhaka City. $J$.
Bangladesh Academy of Sci., 37(1): 57-63.

Ojumba, U. 2005. C. Increasing incidence of bacterial resistance to antibiotics by isolates from the urinary tract. Niger J. Clin. Pract., 8: 107-9.

Onanuga, A., Awhowho, G.O. 2012. Antimicrobial resistance of Staphylococcus aureus from patients with urinary tract infections with Yenagoa, Nigeria. J. Pharm. Bioallied Sci., 4(3): 226-30.

Orrett, F.A., Davis, G.K. 2003. A comparison of antimicrobial susceptibility profile of urinary pathogens for the years, 1999 and 2003. West Indian Medical J., 55 (2): 95-9.

Prakash, D., Saxena, R.S. 2013. Distribution and Antimicrobial Susceptiblity Pattern of Bacterial Pathogens Causing Urinary Tract Infection in Urban Community of Meerut City, India. ISRN Microbiol., http://dx.doi.org/10.1155/2013/749629

Rafay, A.M., Nsanze, H.N. 2003. Multi Drug resistance of Esch. coli from the urinary tract. Saudi Med. J., 24(3): 261-4.

Sana, M. Al-Ali, Asia, S. Al-Hamdan Fotooh, A. Al-JarkJamila, M.K. AlFarajSamia S.A. Mussalem. 2005. Antimicrobial resistance pattern in urinary tract pathogens and its impact on empirical therapy in general practice, Kuwait Med. J., 37(1): 22-27.

Shah, D.A., Wasim, S., Essa Abdullah, F. 2015. Antibiotic resistance pattern of Pseudomonas aeruginosa isolated from urine samples of Urinary Tract Infections patients. PaK. J. Med. Sci., 31(2): 341-345.

Shanti, J., Kayathri, S. 2012. Incidence, distribution and antibiogram of uropathogens isolated from patients 
with urinary tract infections. $A d v$. Appl. Sci. Res., 3(6): 3410-4.

Somashekara, S.C., Deepalaxmi, S., Jagannath, N., Ramesh, B., Laveesh, M.R., Govindadas, D. 2014. Retrospective analysis of antibiotic resistance pattern to urinary pathogens in a Tertiary Care Hospital in South India. J. Basic Clin. Pharm., 5(4):105108.

Sussman, M. 1998. In: Topley and Wilson's Microbiology and Microbial infections. HauslerJr, Sussman M editors. $9^{\text {th }}$ edition. Arnold, 601-621.

Tankhiwale, S.S., Jalgaonkar, S.V., Ahamad, S., Hassani, U. 2004. Evaluation of extended spectrum beta lactamase in urinary isolates. Indian $J$. Med. Res., 120: 553-6.

Wagenlehner, F.M., Niemetz, A., Dalhoff, A., Naber, K.G. 2002. Spectrum and antibiotic resistance of uropathogens from hospitalized patients with urinary tract infection: 1994-2000. Int. J. Antimicrob. Agents, 19: 557-64.

Warren, J.W., Abrutyn, E., Hebel, J.R., Johnson, J.R., Schaeffer, A.J., Stamm, W.E. 1999. Guidelines for antimicrobial treatment of uncomplicated acute bacterial cystitis and acute pyelonephritis in women. Clinical Infectious Dis., 29(4): 745-58.

\section{How to cite this article:}

Puneet Bhatt, Rajat Jagani, Praveer Ranjan, Mohd Ashraf Ali Namaji, Rathi. 2017. Antimicrobial Resistance Pattern of Bacterial Isolates from Urinary Tract Infections at a Tertiary Care Centre. Int.J.Curr.Microbiol.App.Sci. 6(1): 175-183.

doi: http://dx.doi.org/10.20546/ijcmas.2017.601.022 